\title{
EKUITAS MEREK PRODUK CAP KAKI TIGA: PENGUJIAN MODEL CONSUMER-BASED BRAND EQUITY
}

\author{
Joko Pramono \\ Program Studi Magister Manajemen Universitas Tarumanagara \\ jpramono14@gmail.com
}

\begin{abstract}
This study examines consumer-based brand equity of Cap Kaki Tiga-label branding and relative significance of brand awareness, perceived quality, and brand association on brand loyalty. As additional, this study aims to test the role of brand loyalty as a mediator on the relationship of its predictors on brand equity. A survey instrument was developed, scale measures were pretested, and the final survey was administered directly to 210 respondents. Based on Aaker's conceptual framework, a structural equation model (SEM) was designed to analyse the proposed relationships. A causal order between brand equity dimensions was established. The results suggest that the positive effects of brand awareness, perceived quality and brand association on brand loyalty, and overall brand equity are mediated by brand loyalty. Marketing managers should focus on brand loyalty in order to increase overall brand equity, and should give special attention to brand awareness, since it is the factor with the strongest impact on brand loyalty.
\end{abstract}

Keywords: consumer-based brand equity, brand awareness, perceived quality, brand association, brand loyalty, brand equity

\section{PENDAHULUAN}

Membangun dan mengelola merek yang kuat dianggap sebagai salah satu tugas paling penting dalam manajemen merek (brand management) untuk dapat memberikan kontribusi maksimal bagi perusahaan. Hal ini disebabkan karena pelanggan yang memiliki kesetian pada sebuah merk akan memberikan kesulitan kepada pesaing untuk memasuki pasar, sehingga semua aktivitas pemasaran lebih banyak diarahkan pada penciptaan merk yang kuat. Ekuitas merek dapat dinyatakan sebagai aset tak berwujud yang dapat membawa banyak keuntungan bagi perusahaan.

Perusahaan dapat memanfaatkan merek dengan ekuitas tinggi melalui perluasan merek dan mengurangi kemungkinan kegagalan produk. Meskipun proses pembuatan dan desain produk dapat dengan mudah diduplikasi, namun merk-merk tertentu tetap menjadi pilihan konsumennya, meskipun tanpa promosi yang dilakukan secara masif. Hal ini menunjukkan bahwa ekuitas merek yang tinggi dapat meningkatkan efisiensi dalam periklanan, selain itu, ekuitas merek yang tinggi menyebabkan kepuasan lebih pada konsumen (Aaker, dalam Ding dan Tseng, 2015). Pentingnya peran ekuitas merek kemudian membawa perhatian yang besar di dunia akademik dan praktisi bisnis, khususnya pemasaran.

Model ekuitas merek secara umum mengadaptasi model yang dikembangkan oleh Aaker (1996) yaitu consumer-based brand equity. Model ini mengidentifikasi berbagai anteseden seperti brand awareness, brand association, perceived quality, dan brand loyalty, serta berbagai asset merek seperti paten, merek dagang dan saluran distribusi. Namun berbagai hasil penelitian sebelumnya memberikan banyak kesimpulan yang berbeda mengenai model tersebut dengan cara mengganti berbagai faktor yang dianggap relevan mempengaruhi ekutitas merek.

Penelitian Liao, Wu, Rivas, \& Ju (2017) menemukan bahwa faktor kognitif, pengalaman dan faktor pemasaran memiliki pengaruh signifikan terhadap ekuitas merek. Model berbeda diajukan oleh Girard, Trapp, Pinar, Gulsoy, \& Boyt (2017) menggunakan variabel kesadaran merek dan kualitas yang dirasakan (perceived quality). Risiko, nilai yang 
dirasakan, dan loyalitas merek memiliki peran mediasi yang signifikan dalam menciptakan ekuitas merek. Selanjutnya Torres, Augusto, \& Lisboa (2015) menyimpulkan bahwa dampak positif dari persepsi kualitas dan kesadaran merek terhadap ekuitas merek secara keseluruhan dimediasi oleh loyalitas merek.

Di sisi lain, dalam penelitian sebelumnya berhasil diidentifikasi bahwa hubungan kausal antara dimensi ekuitas merek tidak mencapai kesepakatan hasil. Misalnya, Buil et al. (2013) menyarankan bahwa kualitas yang dirasakan memiliki efek kecil tetapi negatif pada loyalitas merek, dan Gil et al. (2007) tidak menemukan hubungan yang signifikan antara persepsi kualitas dan loyalitas merek, hasil yang bertentangan dan tidak konsisten dengan teori (Keller, 2006). Bahkan, beberapa studi memberikan kesimpulan bahwa hubungan kausal antara dimensi ekuitas merek merupakan hubungan kausal tidak jelas, misalnya, loyalitas merek dapat mempengaruhi ekuitas merek dan sebaliknya juga dapat dipengaruhi oleh ekuitas merek (Wang dan Finn, 2013). Adanya perbedaan dalam mengidentifikasi model proses pada ekuitas merek ini menunjukkan bahwa riset di bidang ini masih perlu dikembangkan dan diklarifikasi ulang.

Berdasarkan uraian latar belakang, maka pokok permasalahan yang ingin diklarifikasi adalah : (1) apakah kesadaran merek (brand awareness), kualitas yang dirasakan (perceived quality), dan asosiasi merek (brand association) berpengaruh terhadap loyalitas merek (brand loyalty) ?; (2) apalah loyalitas merek berpengaruh terhadap ekuitas merek; dan (3) apakah loyalitas merek (brand loyalty) berperan sebagai pemediasi hubungan kesadaran merek (brand awareness), kualitas yang dirasakan (perceived quality), dan asosiasi merek (brand association) terhadap ekuitas merek ?

\section{TINJAUAN TEORI DAN HIPOTESIS}

\section{Hubungan Kesadaran merek dengan loyalitas merek}

Kesadaran merek didefinisikan sebagai kekuatan kehadiran merek di pikiran. Kesadaran merek yang tinggi, yang dihasilkan dari asosiasi merek, adalah sinyal kualitas yang membantu konsumen dalam mengambil keputusan pembelian. Oleh karena itu, brand awareness dapat dipandang sebagai anteseden loyalitas merek. Kesadaran merek terkait dengan "kemampuan calon pembeli untuk mengenali dan mengingat bahwa merek adalah anggota kategori produk tertentu" (Torres et al., 2015), dan pengenalan merek dan hasil recall dari interaksi berkepanjangan individu terhadap Merek (Keller, 2013). Kenyataannya, tingkat kesadaran merek bisa menjadi konsekuensi dari ruang lingkup dan frekuensi penampilan merek, yang terkait dengan belanja iklan merek (Keller, 2013). Oleh karena itu, semakin tinggi belanja iklan, tingkat kesadaran yang lebih tinggi cenderung terjadi. Meskipun kesadaran mungkin tidak selalu mengarah pada pembelian, namun kesadaran merek yang lebih besar dapat menyebabkan konsumen meningkatkan preferensi merek mereka. Selanjutnya, agar loyal terhadap merek tertentu konsumen harus sadar akan merek. Dukungan empiris mengenai hubungan antara kesadaran merek dengan loyalitas merek antara lain dibuktikan oleh Torres et al., (2015) dan Nguyen et al., (2011) yang menemukan efek langsung kesadaran merek terhadap loyalitas merek. Dengan demikian hipotesis yang diajukan adalah :

H1a : Ada hubungan positif antara kesadaran merek dan loyalitas merek

\section{Hubungan kualitas yang dirasakan dengan loyalitas merek}

Kualitas yang dirasakan mengacu pada persepsi pelanggan terhadap keseluruhan kualitas atau keunggulan produk atau layanan sehubungan dengan tujuan dan pertimbangan relative terhadap merek sejenis. dan memainkan peran penting dalam penjelasan loyalitas merek. Kualitas yang dirasakan didasarkan pada penilaian konsumen tentang atribut merek yang bermakna bagi mereka, yaitu persepsi. Ketika konsumen merasa bahwa merek memiliki kualitas tinggi dibandingkan dengan merek lain dalam satu set kompetitif, mereka cenderung 
memberi nilai tinggi pada merek, mendorong keputusan pembelian dan pembelian kembali mereka. Penelitian sebelumnya menunjukkan bahwa persepsi kualitas mempengaruhi loyalitas merek (Torres et al., 2015; Nguyen et al., 2011) sehingga hipotesis diajukan adalah sebagai berikut :

$\mathrm{H} 1 \mathrm{~b}$ : Ada hubungan positif antara kualitas dan loyalitas merek

\section{Hubungan asosiasi merek dengan loyalitas merek}

Brand association (BA) merupakan segala sesuatu yang terhubung di memori konsumen terhadap suatu merek. Pada umumnya asosiasi merek (terutama yang membentuk brand image-nya) menjadi pijakan konsumen dalam keputusan pembelian dan loyalitas pada merek tersebut (Keller, 2013). Semakin dalam seseorang memikirkan informasi produk dan menghubungkannya dengan pengetahuan merek yang ada, semakin kuat asosiasi merek yang dihasilkan. Dua faktor yang memperkuat keterkaitan dengan informasi apapun adalah relevansi pribadinya dan konsistensi dari waktu ke waktu. (Keller, 2013). Seperti yang dikemukakan oleh Cho et al. (2015), asosiasi merek dapat mempengaruhi loyalitas. Das (2014) berpendapat bahwa dalam pengambilan keputusan pembelian, kesadaran merek memainkan peran sentral. Buil et al., (2013) membuktikan efek asosiasi merek pada loyalitas merek. Berdasarkan uraian ini maka hipotesis 1c yang diajukan adalah :

H1c : Ada hubungan positif antara asosiasi merek dan loyalitas merek

\section{Hubungan Loyalitas merek Dengan Ekuitas merek}

Loyalitas merek dapat dinyatakan sebagai dimensi inti dari ekuitas merek. Hal ini sesuai dengan definisinya yang mencerminkan kemungkinan seorang pelanggan berpindah ke merek lain. Loyalitas atau kesetiaan merek juga bisa dikaitkan dengan sejauh mana pelanggan merasa bahwa mereka selaras dengan merek, yang mencerminkan sifat hubungan merek-pelanggan (Keller, 2013). Di sisi lain, ekuitas merek secara keseluruhan dianggap sebagai preferensi global untuk merek dibandingkan alternatif serupa (Torres, et al., 2015) dan dapat berupa nilai tambah pada produk bermerek relatif terhadap produk tidak bermerek (Kim and Hyun, 2011). Penelitian sebelumnya menunjukkan bahwa loyalitas merek dan ekuitas merek secara keseluruhan terkait erat (Torres et al., 2015; Ding dan Tseng, 2015 ). Dengan demikian hipotesis yang diajukan adalah :

$\mathrm{H} 2$ : ada hubungan positif antara loyalitas merek dengan ekuitas merek

\section{Loyalitas merek sebagai mediasi}

Loyalitas merek merupakan komitmen yang kuat untuk membeli kembali atau menolak untuk memberi produk atau layanan lain, sehingga menyebabkan pembelian merek atau merek yang berulang-ulang, Loyalitas merek adalah bagian lain dari hubungan pelanggan dengan merek. Sedangkan hubungan langsung antara dimensi ekuitas merek dan keseluruhan ekuitas merek tidak didukung dalam beberapa penelitian (misalnya Atilgan et al., 2005; Gil et al., 2007), loyalitas merek tampaknya terkait erat dengan keseluruhan ekuitas merek (Atilgan et al., 2005; Gil et al., 2007). Selanjutnya, loyalitas merek dianggap sebagai sebuah konstruksi didahului oleh tiga dimensi lainnya (Gil et al., 2007), seperti kesadaran merek, kualitas yang diterima, dan asosiasi merek. Sejalan dengan pendapat tersebut, penelitian Torres et al., (2015) menunjukkan bahwa efek positif dari persepsi kualitas dan kesadaran merek terhadap ekuitas merek secara penuh dimediasi oleh loyalitas merek. Sejalan dengan riset sebelumnya, penelitian ini mengajukan hipotesis :

H3 : Loyalitas merek merupakan mediator hubungan kesadaran merek, kualitas yang dirasakan, dan asosiasi merek terhadap loyalitas merek 


\section{METODE PENELITIAN \\ Pendekatan Penelitian}

Penelitian ini menggunakan metode deskriptif dan survey. Penelitian dengan metode deskriptif, yaitu studi yang intesif dan terperinci mengenai suatu obyek yang dilakukan serta berpedoman pada kuisioner pada pengamatan langsung terhadap hal-hal yang tidak tercakup dalam kuisioner. Melalui metode ini data dan fakta yang berkaitan dengan penelitian dihimpun untuk mendapatkan gambaran yang komprehensif mengenai obyek yang diteliti dan diprediksi situasi masa depan perusahaan. Data-data dan fakta dianalisis sebagai dasar untuk mencari solusi atas masalah yang ada dengan teori dan pemikiran logis.

\section{Populasi dan Sampel}

Secara umum, SEM membutuhkan ukuran sampel yang lebih besar dari pendekatan multivariat lainnya. SEM tidak dapat diandalkan jika menggunakan sampel kecil (Hair et al., 2006). Kline (2015) mengkategorikan ukuran sampel kurang dari 100 (kecil), 100-200 (sedang), dan lebih dari 200 (besar). Ukuran sampel berkisar 100-200 merupakan ukuran sampel yang memadai untuk model SEM sederhana (Hair et al., 2006; Schumacker dan Lomax, 2010). Sampel penelitian ditentukan sebesar 210 orang responden didasarkan para pertimbangan rasio jumlah indikator $\mathrm{x} 10$.

\section{Pengukuran Variabel}

Pengukuran variabel diadaptasi dari berbagai model pengukuran yang dikembangkan oleh penelitian sebelumnya. Berikut ini disajikan model pengukuran tiap variabel :

Tabel 1. Operasionalisasi Variabel

\begin{tabular}{|c|c|c|}
\hline Variabel & Indikator & Sumber \\
\hline $\begin{array}{l}\text { Ekuitas merek } \\
\text { BE }\end{array}$ & $\begin{array}{l}\text { 1. Rasionalisasi pembelian } \\
\text { 2. Kesamaan fitur } \\
\text { 3. Kesamaan kualitas } \\
\text { 4. Kemiripan merek lain }\end{array}$ & $\begin{array}{l}\text { Yoo \& Donthu, (2001) dan } \\
\text { Gillard et al., (2016) }\end{array}$ \\
\hline $\begin{array}{l}\text { Loyalitas merek } \\
\mathrm{BL}\end{array}$ & $\begin{array}{l}\text { 1. Tidak membeli merek lain } \\
\text { 2. Setia } \\
\text { 3. Merekomendasikan } \\
\text { 4. Membeli teratur }\end{array}$ & $\begin{array}{l}\text { Yoo \& Donthu, (2001) dan } \\
\text { Gillard et al., (2016) }\end{array}$ \\
\hline $\begin{array}{l}\text { Kesadaran merek } \\
\text { BAW }\end{array}$ & $\begin{array}{l}\text { 1. Pengenalan merek } \\
\text { 2. Pengetahuan } \\
\text { 3. Pengenalan produk } \\
\text { 4. Simbol / logo }\end{array}$ & $\begin{array}{l}\text { Yoo \& Donthu, (2001) dan } \\
\text { Gillard et al., (2016) }\end{array}$ \\
\hline $\begin{array}{l}\text { Kualitas dirasakan } \\
\text { PQ }\end{array}$ & $\begin{array}{l}\text { 1. Keandalan } \\
\text { 2. Kualitas (reverse) } \\
\text { 3. Konsitensi } \\
\text { 4. Kualitas } \\
\text { 5. Fungsi }\end{array}$ & $\begin{array}{l}\text { Yoo \& Donthu, (2001) dan } \\
\text { Gillard et al., (2016) }\end{array}$ \\
\hline $\begin{array}{l}\text { Asosiasi merek } \\
\text { BAS }\end{array}$ & $\begin{array}{l}\text { 1. Citra positif } \\
\text { 2. Kemapanan merek } \\
\text { 3. Pengguna lama } \\
\text { 4. Pengetahuan varian }\end{array}$ & $\begin{array}{l}\text { Yoo \& Donthu, (2001) dan } \\
\text { Gillard et al., (2016) }\end{array}$ \\
\hline
\end{tabular}

Sumber : diolah

\section{HASIL DAN PEMBAHASAN}

Analisis hasil pengolahan data pada tahap full model SEM dilakukan dengan melakukan uji kesesuaian dan uji statistik. Berdasarkan evaluasi atas kecocokan model, 
indeks kecocokan absolute meliputi p value, RMSEA, GFI, standard RMR, satu diantaranya memenuhi kecocokan data yaitu RMSEA $0.039<0.08$. Sedangkan nilai $\mathrm{p}$ value chi-square sebesar 0.000 (kurang baik). Indeks kecocokan incremental yang terdiri dari CFI, NFI, NNFI, RFI, dan IFI, seluruhnya memiliki memiliki kecocokan baik (nilai > 0.90) kecuali AGFI yang berada pada tingkat marginal fit. Memperhatikan temuan ini, maka dapat dinyatakan bahwa secara mayoritas evaluasi indeks-indeks kecocokan model sudah memenuhi kriteria goodness offit.

\section{Pengujian Hipotesis dan Pembahasan}

Parameter uji hipotesis menggunakan perbandingan nilai t, yaitu jika nilai t hitung > dari t table (1.96), maka h0 ditolak dan h1 diterima. Pada model loyalitas merek (BL) diperoleh nilai $\mathrm{R}^{2}$ sebesar 0.377 , merupakan koefisien deterimasi dari model loyalitas merek berdasarkan tiga variabel eksogen yaitu kesadaran merek (BAW), kualitas yang diterima (PQ) dan asosiasi merek (BAS). Dengan demikian dapat dinyatakan bahwa variasi loyalitas merek (BL) sebesar 37.7\% (dibulatkan 38\%) mampu dijelaskan oleh kesadaran merek (BAW), kualitas yang diterima (PQ) dan asosiasi merek (BAS), dan sisanya 62\% dijelaskan oleh variabel lain di luar model.

Substruktural kedua menempatkan ekuitas merek (BE) sebagai endogen dan loyalitas merek (BL) sebagai eksogen. Melalui persamaan structural diperoleh nilai $\mathrm{R}^{2}$ sebesar 0.138 atau variasi ekuitas merek sebesar $13.8 \%$ (dibulatkan 14\%) dapat dijelaskan oleh loyalitas merek, dan sisanya $86 \%$ dipengaruhi faktor lain di luar model. Selanjutnya, penjelasan mengenai masing-masing pengujian hipotesis adalah sebagai berikut :

Estimasi untuk pengujian pengaruh kesadaran merek terhadap loyalitas merek menunjukkan nilai koefisien unstandard sebesar 0.296 dan t hitung sebesar 2.665. Nilai $\mathrm{t}$ hitung sebesar 2.665 lebih besar dari 1,96. Dengan demikian dapat disimpulkan hipotesis yang diajukan terbukti, atau menerima hipotesis alternative $\left(\mathrm{H}_{1}\right)$ yang menyatakan adanya pengaruh kesadaran merek terhadap loyalitas merek. (Ho ditolak, H1 diterima). Koefisien jalur antara asosiasi merek (BAS) terhadap loyalitas merek (BL) menunjukkan nilai koefisien unstandard sebesar 0.234 dan $\mathrm{t}$ hitung sebesar 2.584. Nilai t hitung tersebut diperoleh memenuhi syarat untuk penerimaan $\mathrm{H} 1$ yaitu nilai t hitung yang lebih besar dari 1,96. Dengan demikian dapat disimpulkan asosiasi merek memiliki pengaruh positif dan signifikan terhadap loyalitas merek.

Koefisien jalur antara loyalitas merek (BL) terhadap ekuitas merek (BE) menunjukkan nilai koefisien unstandard sebesar 0.372 dan t hitung sebesar 4.223. Nilai $t$ hitung tersebut diperoleh memenuhi syarat untuk penerimaan $\mathrm{H} 1$ yaitu nilai t hitung yang lebih besar dari 1,96. Dengan demikian dapat disimpulkan loyalitas merek memiliki pengaruh positif dan signifikan terhadap ekuitas merek.

Peran loyalitas merek sebagai mediator hubungan kesadaran merek (BAW), kualitas yang diterima (PQ) dan asosiasi merek (BAS) terhadap ekuitas merek dilihat dari nilai "Indirect Effects of KSI on ETA " berikut ini :

Hasil perhitungan menunjukkan bahwa pengaruh tidak langsung kesadaran merek (BAW) terhadap ekuitas merek (BE) melalui loyalitas merek (BL) adalah sebesar sebesar 0.110. Angka ini merupakan perkalian dari jalur BAW $\rightarrow$ BL dan BL $\rightarrow$ BE yaitu $0.30 \times 0.37$ $=0.110$. Nilai $\mathrm{t}$ hitung pada pengaruh tidak langsung kesadaran merek terhadap ekuitas merek adalah sebesar 2.405 (> 1.96) dan dinyatakan signifikan. Dengan demikian dapat disimpulkan bahwa loyalitas merek terbukti sebagai mediator hubungan kesadaran merek (BAW) dengan ekuitas merek (BE).

Pengaruh tidak langsung kualitas yang diterima (PQ) terhadap terhadap ekuitas merek (BE) melalui loyalitas merek (BL) adalah sebesar sebesar 0.094. Angka ini merupakan perkalian dari jalur PQ $\rightarrow$ BL dan BL $\rightarrow$ BE yaitu $0.25 \times 0.37=0.094$. Nilai t hitung pada pengaruh tidak langsung kualitas yang diterima terhadap ekuitas merek adalah sebesar 2.094 
(> 1.96) dan dinyatakan signifikan. Dengan demikian dapat disimpulkan bahwa loyalitas merek terbukti sebagai mediator kualitas yang diterima (PQ) dengan ekuitas merek (BE).

Pengaruh tidak langsung asosiasi merek (BAS) terhadap terhadap ekuitas merek (BE) melalui loyalitas merek (BL) adalah sebesar 0.087. Angka ini merupakan perkalian dari jalur BAS $\rightarrow$ BL dan BL $\rightarrow$ BE yaitu $0.23 \times 0.37=0.087$. Nilai t hitung pada pengaruh tidak langsung kualitas yang diterima terhadap ekuitas merek adalah sebesar 2.125 (> 1.96) dan dinyatakan signifikan. Dengan demikian dapat disimpulkan bahwa loyalitas merek terbukti sebagai mediator asosiasi merek (BAS) dengan ekuitas merek (BE).

Secara keseluruhan, penelitian ini berhasil membuktikan seluruh hipotesis yang diajukan :

Tabel 3. Perhitungan Pengaruh Langsung (direct effect / DE) dan Tidak Langsung (indirect effect-IE)

\begin{tabular}{lllll}
\hline Hipotesis & Hubungan & Koef & t & Kesimpulan \\
\hline H1a & BAW --> BL & 0.296 & 2.665 & Signifikan \\
H1b & PQ --> BL & 0.252 & 2.596 & Signifikan \\
H1c & BAS --> BL & 0.234 & 2.584 & Signifikan \\
H2 & BL --> BE & 0.372 & 4.223 & Signifikan \\
Indirect & & & & \\
H3a & BAW --> BL --> BE & 0.110 & 2.405 & Signifikan \\
H3b & PQ --> BL --> BE & 0.094 & 2.094 & Signifikan \\
H3c & BAS --> BL --> BE & 0.087 & 2.125 & Signifikan \\
\hline
\end{tabular}

\section{KESIMPULAN DAN SARAN}

Beberap kesimpulan yang diperoleh dari hasil analisis antara lain: pertama, ditemukan hubungan positif dan signifikan kesadaran merek dengan loyalitas merek. Nilai koefisien positif sebesar 0.296 menunjukkan bahwa semakin tinggi kesadaran merek maka semakin tinggi pula loyalitas merek pada produk yang diteliti. Temuan ini mendukung penelitian Torres et al., (2015) dan Nguyen et al., (2011) yang menemukan efek langsung kesadaran merek terhadap loyalitas merek.

Kedua, ditemukan hubungan positif dan signifikan kualitas yang dirasakan dengan loyalitas merek. Nilai koefisien positif sebesar 0.252 menandakan bahwa semakin tinggi kualitas yang dirasakan oleh konsumen maka akan semakin besar pula loyalitas mereka terhadap merek tersebut. Temuan ini mendukung penelitian penelitian Torres et al., (2015) dan Nguyen et al., (2011) yang sebelumnya juga menemukan efek positif kualitas terhadap loyalitas konsumen pada merek tertentu. Ketiga, ditemukan hubungan positif dan signifikan asosiasi merek dengan loyalitas merek. Nilai koefisien positif sebesar 0.234 menunjukkan bahwa semakin tinggi asosiasi merek maka semakin tinggi pula loyalitas merek pada produk yang diteliti. Temuan ini mendukung penelitian Torres et al., (2015) dan Nguyen et al., (2011) yang menemukan efek langsung kesadaran merek terhadap loyalitas merek. Penelitian ini sejalan dengan temuan Cho et al. (2015), Das (2014) dan Buil et al., (2013) membuktikan efek asosiasi merek pada loyalitas merek.

Keempat, ditemukan hubungan positif dan signifikan loyalitas merek dengan ekuitas merek. Nilai koefisien positif sebesar 0.372 menunjukkan bahwa semakin tinggi loyaliyas merek maka semakin tinggi pula ekuitas merek pada produk yang diteliti. Hasil ini sejalan dengan penelitian sebelumnya menunjukkan bahwa loyalitas merek dan ekuitas merek secara keseluruhan terkait erat (Torres et al., 2015; Ding dan Tseng, 2015 ). Terakhir, loyalitas merek merupakan mediator hubungan kesadaran merek, kualitas yang diterima dan asosiasi merek terhadap loyalitas merek. Hasil uji pengaruh tidak langsung menunjukkan bahwa loyalitas merek dapat menjadi pemediasi kesadaran merek, kualitas yang diterima dan asosiasi merek. Dengan demikian, penelitian ini berhasil membuktikan penelitian Gil et al., 
(2007) dan Torres et al., (2015) yang menunjukkan bahwa efek positif dari persepsi kualitas dan kesadaran merek terhadap ekuitas merek secara penuh dimediasi oleh loyalitas merek.

\section{DAFTAR PUSTAKA}

Aaker, D. A. (1996). Measuring brand equity across products and markets. California Management Review, 38, 102-120

Aaker, J. L. (1997). Dimensions of brand personality. Journal of Marketing Research, 34, $347-356$

Buil, L., de Chernatony, L., and Martinez, E. (2013). Examining the role of advertising and sales promotions in brand equity creation. Journal of Business Research, 66, 115-122

Ding, Cherng and Tseng, Timmy H. (2015). The relationships among brand experience, hedonic emotions, and brand equity. European Journal of Marketing. 49(7/8), 9941015.

Girard, T., Trapp, P., Pinar, M., Gulsoy, T., \& Boyt, T. E. (2017). Consumer-based brand equity of a private-label brand: Measuring and examining determinants. Journal of Marketing Theory and Practice, 25(1), 39-56.

Hair, J. F., W. C. Black, B. J. Babin, R. E. Anderson, and R. L. Tatham. (2006). Multivariate Data Analysis. Upper Saddle River, NJ: Prentice Hall.

Keller, K.L. (2012). Strategic Brand Management: Building, Measuring, and Managing Brand Equity, 4th Edition. Pearson.

Keller, K. L., \& Lehmann, D. R. (2006). Brands and branding: Research findings and future priorities. Marketing science, 25(6), 740-759.

Kim, J.H. and Hyun, Y.J. ( 2011 ). A model to investigate the influence of marketing-mix efforts and corporate image on brand equity in the IT software sector. Industrial Marketing Management, 40(3), 424 - 438 .

Kline, R. B. (2015). Principles and Practices of Structural Equation Modeling. New York, NY: Guilford Publications.

Kotler, P. and Keller, K. (2012), Marketing Management; 14th ed., Prentice Hall, Upper Saddle River, NJ

Liao, Ying-Kai; Wu, Wann-Yih; Amaya Rivas, Adriana A, and Ju, Teresa Lin. (2017). Cognitive, Experiential, And Marketing Factors Mediate The Effect Of Brand Personality On Brand Equity. Social Behavior and Personality; 45(1), 1-18.

Nguyen, Tho D; Barrett, Nigel J and Miller, Kenneth E. (2011). Brand loyalty in emerging markets. Marketing Intelligence \& Planning. 29(3), 222-232.

Schumacker, R.E., Lomax, R.G. (2010). A Beginner's Guide To Structural Equation Modeling. Taylor and Francis Group, LLC

Torres, Pedro Marcelo., Augusto, Mário Gomes and Lisboa, João Veríssimo. (2015) Determining the causal relationships that affect consumer-based brand equity: The mediating effect of brand loyalty. Marketing Intelligence \& Planning, 33(6), 944-956 


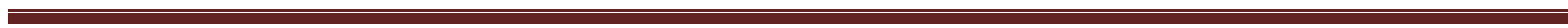
$\cdot$ 